\title{
Adult Attachment Styles as Predictors of Different Types of Ingroup Identification
}

\author{
Milen Milanov*, Mark Rubin**, Stefania Paolini**
}

The correct reference for this article is as follows:

Milanov, M., Rubin, M., \& Paolini, S. (2013). Adult attachment styles as predictors of different types of ingroup identification. Bulgarian Journal of Psychology, 1-4, 175-186.

This self-archived version is provided for non-commercial, scholarly purposes only.

The primary goal of the present research was to explore the relationship between adult attachment styles and four different types of identification with social groups. The results confirmed predictions and revealed that particular prototypic attachment styles are associated with an increase in only certain types of ingroup identification. People with secure attachment style had higher social identification than people with a dismissive-avoidant attachment style. Participants with secure attachment style showed higher communal identification than participants who had either a dismissive-avoidant or a fearful-avoidant attachment style. These findings supported the idea that relationship attachment style has an important effect on the way people identify with their social groups and can serve as a predictor of preferred type of ingroup identity.

\section{Стилове на привързаност при възрастните като предиктори на различни типове вътрешногрупова идентификация}

\footnotetext{
Милен Миланов*, Марк Рюбин**, Стефаниа Паолини**

Основната цел на настоящото изследване е да се проучи връзката между основни стилове на привързаност при възрастните и четири различни типа идентификация със социални групи. Резултатите потвърждават очакванията и разкриват, че определени базисни стилове на привързаност са свързани с увеличение на нивата на конкретни типове вътрешногрупова идентификация. Хората със сигурен стил на привързаност имат по-висока социална идентификация от хората с отхвърлящ стил на привързаност. Участниците със сигурен стил на привързаност показват по-високи нива на общностна идентификация от участниците с отхвърлящ или със страхуващ се стил на привързаност. Тези констатации подкрепят идеята, че стилът на привързаност оказва важно въздействие върху начина, по който хората се идентифицират със социални групи и може да служи като предиктор на предпочитания тип вътрешногрупова идентичност.
}

\footnotetext{
* Department of General, Experimental, and Genetic Psychology, Sofia University "St. Kliment Ohridski”

** School of Psychology, University of Newcastle, Australia
} 


\section{Theoretical Background}

\section{Introduction}

Attachment theory was initially proposed by Bowlby $(1969,1973,1980)$ and further elaborated and developed by a large number of other investigators (e.g., Ainsworth, Blehar, Waters, \& Wall, 1978; Bartholomew \& Horowitz, 1991; Fraley \& Shaver, 2000; Hazan \& Shaver, 1987). Researchers have identified three distinct styles of adult attachment, usually labelled in the literature as secure, anxious/ambivalent, and avoidant (e.g., Ainsworth et al., 1978; Hazan \& Shaver, 1987). Bartholomew and Horowitz (1991) proposed an extended fourcategory typology in adult relationship attachment based on individuals' intrapersonal (selfimage) and interpersonal (image of others) notions. The four attachment styles are secure, preoccupied, fearful-avoidant, and dismissive-avoidant. The first three of these four categories are conceptually similar to Hazan and Shaver's (1987) secure, anxious/ambivalent and avoidant types of adult attachment respectively (Bartholomew \& Horowitz, 1991; Brennan, Shaver, \& Tobey, 1991) ${ }^{2}$. People with secure attachment style have positive views of themselves and others and feel comfortable in both dependent and autonomous relationships. People with preoccupied (anxious/ambivalent) attachment style see themselves as being unworthy in a relationships and struggle for intimacy and approval from positively valued others. People with fearful-avoidant attachment style have negative views about themselves and the others and avoid close involvement in relationships because of fear of rejection. People with dismissive-avoidant attachment style have a sense of worthiness and selfsufficiency and try to maintain a sense of high independence by denying the need of close relationship with unworthy others.

Key theoretical basis of the present study is the distinction between centrality, social, communal, and interdependent identification as four different types of identification with social groups (Milanov, Rubin \& Paolini, 2012; Milanov, Rubin \& Paolini, in press). Centrality refers to the salience of the group and the group membership together with the importance of the group for an individual's self-concept. Social identification is based on the processes of self-categorization and depersonalization. Individuals who have a relatively high level of social identification lose their sense of individuality and perceive themselves as interchangeable members of their group. Communal and interdependent identification, on the other hand, relate more to the specific interpersonal processes through which group members identify with other group members without losing their sense of individuality. The key aspect that separates these two types of ingroup identification is the particular type of relationships (i.e., communal or exchange relationships) between the members of the group. These relationships establish the nature of the interpersonal interaction in the ingroup and determine individuals' expectations that are associated with the group membership.

Previous research has acknowledged the link between individuals' relationship attachment and individuals' identification with groups. Smith, Murphy and Coats (1999) proposed that "adult attachment theory, which has been prominent in recent years as a theory of interpersonal relationships, may be able to shed light on the processes underlying people's identification with social groups as well" (p. 94). According to the authors, relationship attachment and attachment to the group are sometimes correlated but conceptually and empirically different constructs. In the view of the link between attachment style and type of identification then, it could be expected that different types of relationship attachment styles will be related to different types of ingroup identification, and one's attachment style could serve as a predictor of the preferred type of identification with the group.

Crisp et al. (2009) recently investigated the extent to which dispositional differences in attachment style account for increases or decreases in individuals' ingroup identification

\footnotetext{
${ }^{2}$ We will use the terms anxious-ambivalent and preoccupied, and avoidant and fearful-avoidant interchangeably.
} 
following an interpersonal relationship threat. The study operationalized attachment style as a continuous variable that integrates two orthogonal dimensions: attachment avoidance and attachment anxiety. The authors proposed that a perceived relationship distress would result in less anxious individuals identifying with their groups to a greater degree than individuals who are more anxious. As Crisp et al. (2009) summarized their results, the study provided "evidence supportive of the idea that following attachment threat higher attachment anxiety is associated with lower identification with groups while lower attachment anxiety is associated with higher identification with groups" (p. 121).

The above study is important in its successful attempt to apply attachment theory to the area of group identification and to reveal the way in which differences in relationship attachment predict the strength of individual's identification with groups. However, the research seems to confound different types of ingroup identification in its approach. For example, identification with a group of friends and identification with a social category group may be based on different mechanisms and therefore may be qualified in different ways by dispositional differences in attachment style. In support of this assumption, Crisp et al. (2009) noted that the observed attachment threat-attachment style-group identification relationships "are more applicable when the groups involved are lower in entitativity (e.g., social categories like gender) compared to those higher in entitativity (e.g., intimacy groups like friendship groups)" (p. 121). Consequently, consideration of the conceptual differences between different types of ingroup identification is necessary in order to arrive at a clearer picture of attachment style-ingroup identification relationships.

\section{Hypotheses}

In the present research, we tested the idea that each of the prototypic adult attachment styles (i.e., secure, preoccupied, fearful-avoidant, and dismissive-avoidant) are differentially associated with different types of ingroup identification. Unlike Crisp et al. (2008) and Smith et al., (1999), our aim was not to investigate the extent to which the strength of group identification in general is affected by differences in individuals' attachment anxiety and avoidance, but rather to reveal the way in which individuals with different attachment styles enhance different types of identification with their groups.

As explained earlier, different attachment styles are characterized by differences in individuals' perceptions toward interpersonal relationships and presuppose different mechanisms of social behavior and interpersonal interaction. Different types of ingroup identification, on the other hand, are defined by different types of relationships between group members and are associated with differences in individuals' perception towards the group or its members (Milanov, Rubin \& Paolini, 2012; Milanov, Rubin \& Paolini, in press). Drawing on the idea that some types of ingroup identification are based on interpersonal attachment to the group's members, while others are associated with attachment to the group as a whole (Prentice, Miller, Lightdale, 1994), we expected to detect a significant co-variation between ingroup identification and specific adult relationship attachment styles. In particular, we investigated whether prototypic relationship attachment styles predicted different types of ingroup identification.

There is already evidence that attachment style affects individuals' perceptions of similarity with others. Mikulincer, Orbach, and Iavnieli (1998) found that, "people differing in attachment style systematically differed in the extent to which their own self-descriptions were similar to their views of others' traits and opinions" (p. 444). In particular, compared to people with a secure attachment style, avoidant individuals reduced their perceived self-toingroup similarity whereas anxious/ambivalent individuals increased it. From the investigated four types of ingroup identification, only social identification is characterised by the perception of similarity with other group members. Hence, we predict that, relative to secure 
individuals, avoidant individuals should have lower social identification and anxiousambivalent (preoccupied) individuals should have higher social identification.

In addition, research by Gabriel, Carvallo, Dean, Tippin, Renaud (2005) has provided evidence that individuals with avoidant attachment styles scored lower than individuals with nonavoidant attachment styles on a measure of relational self-construal that was modified to relate to friendship (Footnote 1, Gabriel et al., 2005, p. 1571). As explained in previous studies (Milanov, Rubin \& Paolini, 2012; Milanov, Rubin \& Paolini, in press) our idea of communal identification is similar to the idea of relational self-construal applied in the area of ingroup identification. Given the close theoretical parallel between relational self-construal and communal identification, we predict that people with avoidant attachment styles should report less communal identification than people with either secure or anxious/ambivalent attachment styles.

Relative to the above rationale and experimental hypotheses, one final point should be clarified. Different researchers have used categorical, continuous or both methods to measure attachment styles in their studies (Fraley \& Waller, 1998; Gabriel et al., 2005; Mikulincer et al., 1998). The use of any of the two measurement methods usually depends on the specific topic of research and the phenomena that are being investigated. Given that our research focused on the general, prototypic types of adult attachment styles and their basic relationships with particular types of ingroup identification, we decided that measuring attachment style as a categorical variable would be the most appropriate approach, because it would correspond better with the design and the purpose of the current study.

\section{Participants}

\section{Method}

During a four-month period, we collected data from 166 participants from the global internet community. However, 44 participants did not finish the questionnaire. Following previously set rules for such cases, these participants were considered as having withdrawn from the study and their data was deleted. Hence, in the analysis, we used only the data from 122 participants who fully completed the survey.

Participants were 35 men and 87 women ranging in age from 18 to 52 years. The average age was 26.75 years $(S D=8.54)$. All participants had the opportunity to enter a prize draw for one of three electronic gift certificates worth US\$100 each, redeemable from an online store.

\section{Procedure}

The study was presented on the internet using computer based software. All participants completed a single questionnaire consisting of the CSCIIS together with previously established measures of relationship attachment style, social dominance orientation, and ingroup identification. For the purpose of the current investigation, however, we will only focus at the data related to attachment style and ingroup identification.

\section{Measures}

Measure of ingroup identification. In this study, we used a scale that distinguishes between centrality, social, communal, and interdependent identification and allows the assessment of these four different identity types separately from one another. The scale is named Centrality, Social, Communal, and Interdependent Identification Scale (CSCIIS). Our previous research shows that CSCIIS has good psychometric properties and relatively stable factor structure that corresponds with the expected distinction between the investigated identification types (Milanov, Rubin \& Paolini, 2012; Milanov, Rubin \& Paolini, in press). 
The version of CSCIIS that was used in the present study consists of 20 items. Eighteen of these items assess the four different types of ingroup identification (centrality, social identification, communal identification, and interdependent identification) and the other two items measure ingroup identification in general. Respondents indicate their agreement or disagreement with the statements using a 5-point Likert scale from strongly disagree to strongly agree. Example items are "I often think about the fact that I am in my group" (centrality), "I am quite similar to the other people in my group" (social identification), "I empathize with the other people in my group" (communal identification), "I keep track of benefits I have given to other members of my group" (interdependent identification), and "I do not identify with my group" (general identification, reversed).

Measure of relationship attachment style. Bartholomew and Horowitz's (1991) Relationships Questionnaire is a self-report instrument that is designed to assess adult attachment style. The Relationships Questionnaire consists of four sets of statements, each describing a category or style of attachment. Participants choose and rate which set of statements best describes them. The four attachment styles, as initially named and described, are (1) Secure: "It is relatively easy for me to become emotionally close to others. I am comfortable depending on others and having others depend on me. I don't worry about being alone or having others not accept me"; (2) Dismissive-avoidant: "I am comfortable without close emotional relationships. It is very important to me to feel independent and selfsufficient, and I prefer not to depend on others or have others depend on me"; (3) Preoccupied: "I want to be completely emotionally intimate with others, but I often find that others are reluctant to get as close as I would like. I am uncomfortable being without close relationships, but I sometimes worry that others don't value me as much as I value them; and (4) Fearful-avoidant: "I am somewhat uncomfortable getting close to others. I want emotionally close relationships, but I find it difficult to trust others completely, or to depend on them. I sometimes worry that I will be hurt if I allow myself to become too close to others".

As discussed in the beginning, Bartholomew and Horowitz's (1991) secure, preoccupied, and fearful-avoidant categories are conceptually similar to Hazan and Shaver's (1987) secure, anxious-ambivalent, and avoidant types of adult attachment respectively. For the purpose of the current study, attachment style was assessed by asking participants to read Bartholomew and Horowitz's (1991) four descriptions of attachment styles and then to choose the style that best described them or was closest to the way that they are. This approach allowed the direct use of attachment style as a categorical variable in the further analyses.

\section{Reliability and Interitem Correlations of CSCIIS}

Cronbach's alphas for all of the CSCIIS subscales were in the range recommended by Clark and Watson (1992) for good or adequate reliability. For the centrality subscale, $\alpha=.82$; for the social identification subscale, $\alpha=.82$; for the communal identification subscale, $\alpha=$ .51 ; and for the interdependent identification subscale, $\alpha=.82$.

As an additional indicator of internal consistency, the average interitem correlations for all subscales were found to be satisfactory. The mean values were: .43 for the centrality subscale, .53 for the social identification subscale, .26 for the communal subscale, and .53 for the interdependent identification subscale.

\section{Attachment Style and Types of Identification}

Based on the Bartholomew and Horowitz's (1991) Relationships Questionnaire responses, 37 participants reported having a secure attachment style, 33 reported having a dismissive-avoidant attachment style, 19 reported having a preoccupied attachment style, and 
33 reported having a fearful-avoidant attachment styles. To investigate the effect of attachment style on different types of identification, we conducted a series of one-way between-subject ANOVAs using attachment style as an independent factor and each of the subscales of the CSCIIS as dependent variables.

There was a significant effect of attachment style on social identification, $F(3,118)=$ $4.92, p<.01, \eta_{p}{ }^{2}=.11$. Levene's test revealed a significant violation of the assumption of homogeneity of variances $(p=.03)$. Therefore, we used Games-Howell's post hoc test in our follow-up analyses because it is designed for unequal variances and unequal sample sizes. As predicted, participants who had a secure attachment style had significantly higher social identification $(M=3.05)$ than participants who had a dismissive-avoidant attachment style $(M$ $=2.30)$. There were no significant differences in social identification between any of the other attachment styles $(p s>.07)$. Figure 1 shows the mean scores on social identification for the four different attachment style groups.

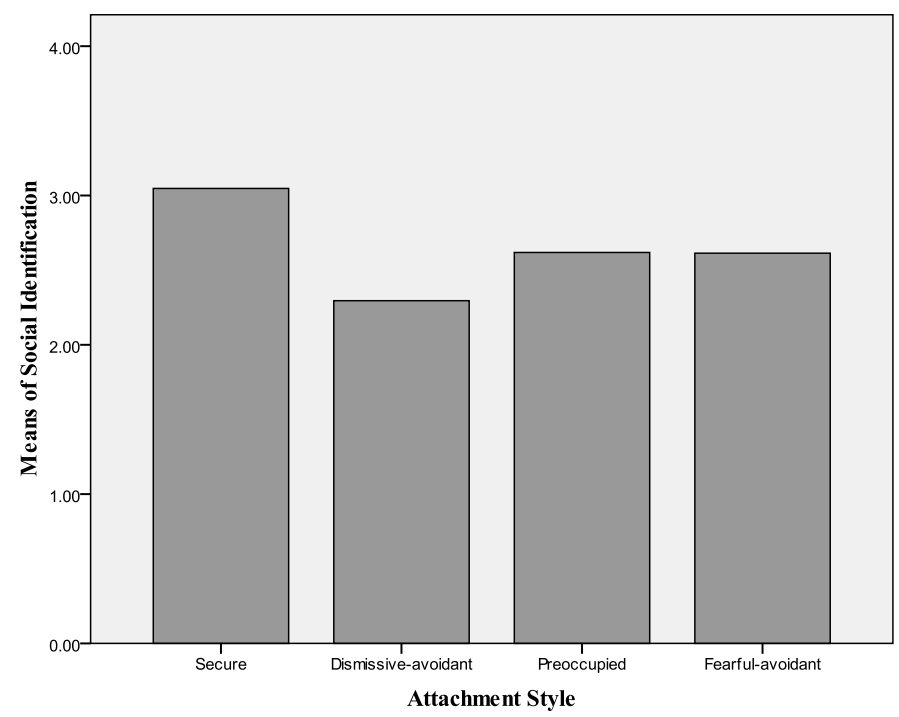

Figure 1. Differences in the mean scores on social identification as a function of attachment style

There was also a statistically significant effect of attachment style on communal identification, $F(3,118)=5.22, p<.01, \eta_{p}{ }^{2}=.12$. In this case, the assumption of homogeneity of variance was not violated $(p=.12)$. The results of a series of LSD post hoc tests showed that participants who had a secure attachment style had significantly higher communal identification $(M=3.92)$ than participants who had either a dismissive-avoidant attachment style $(M=3.32)$ or a fearful-avoidant attachment style $(M=3.47)$. Participants who had a secure attachment style also had significantly higher communal identification $(M=3.92)$ than participants who had a preoccupied attachment style $(M=3.53)$. Figure 2 shows the mean scores on communal identification for the four different attachment style groups. 


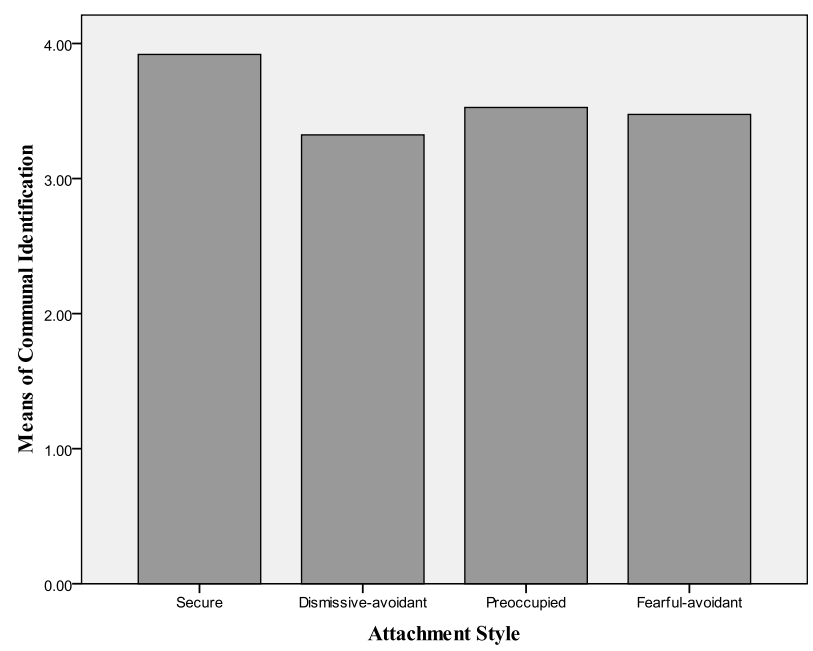

Figure 2. Differences in the mean scores on communal identification as a function of attachment style

There was also a significant effect of attachment style on interdependent identification, $F(3,118)=5.23, p<.01, \eta_{p}{ }^{2}=.12$. Once again, the assumption of homogeneity of variances was violated $(p=.04)$. The results of a series of Games-Howell post hoc tests showed that participants who had a secure attachment style had significantly lower interdependent identification $(M=2.11)$ than participants who had a dismissive-avoidant attachment style $(M=2.88)$. There were no significant differences in interdependent identification between any of the other attachment styles $(p s>.11)$. Figure 3 shows the mean scores on interdependent identification for the four different attachment style groups. No effect of attachment style on centrality was found $(p=.16)$.

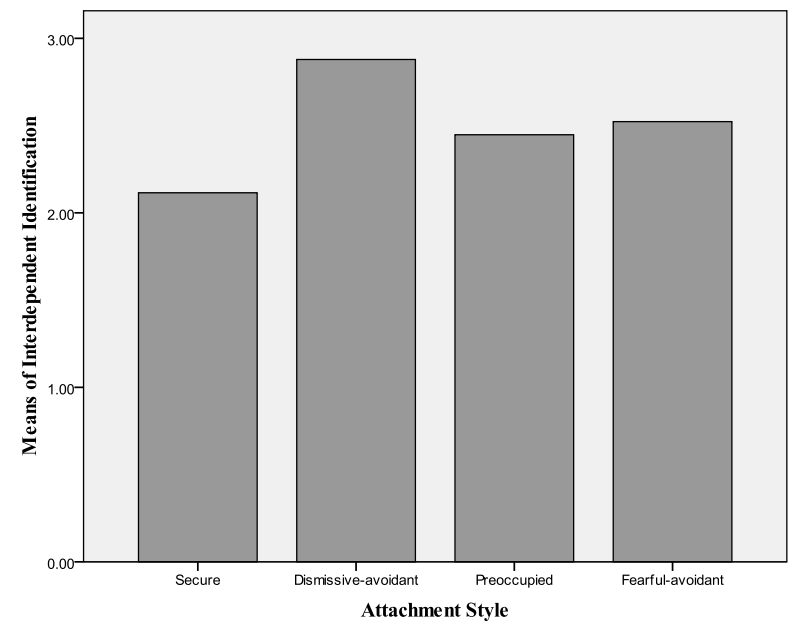

Figure 3. Differences in the mean scores on interdependent identification as a function of attachment style

\section{Discussion \\ Attachment Style as a Predictor of Type of Identification}

The primary goal of this study was to investigate whether different attachment styles could predict type of identification. The data confirmed the majority of the initial hypotheses. People who had a secure attachment style had significantly higher social identification than people who had a dismissive-avoidant attachment style. Participants who had a secure attachment style had significantly higher communal identification than participants who had 
either a dismissive-avoidant attachment style or a fearful-avoidant attachment style. Participants with secure attachment style also showed higher communal identification than participants who had preoccupied (anxious/ambivalent) attachment style. These findings suggest that, compared to avoidant and preoccupied individuals, secure individuals are more likely to engage in close, friendly relationships with other group members (communal identification). At the same time, secure individuals are less concerned than avoidant individuals in seeing themselves, or being seen, as similar to other group members (social identification).

We did not find any evidence showing higher levels of social identification for preoccupied (anxious/ambivalent) individuals compared to secure individuals. The lack of support for this prediction could be related to the relatively small number of participants who reported having a preoccupied attachment style $(N=19)$.

In addition to the above results, the data showed a trend that was not initially predicted. Participants with secure attachment style scored significantly lower on interdependent identification than participants with dismissive-avoidant attachment styles. This result implies that dismissive-avoidant individuals would generally prefer less close, exchange based relationships with other group members that allow identification without sacrificing self-interests and perception of similarity between members.

\section{Study Limitations}

It should be noted here that this study employed a single self-report measure of adult attachment style in which attachment style was assessed as a categorical rather than continuous variable. Given that this research only looked at general patterns of adult attachment as predictors of types of identification, this approach served well for the specific purpose of this investigation. However, it is recommended that researchers who are interested in more complex interactions between attachment style and type of ingroup identification use combined sets of measures (e.g. attachment interviews, q-sort assessments, questionnaires and rating scales).

\section{Summary}

The theoretical framework of this study was based on the distinction between different types of ingroup identification and their expected different interactions with individuals' relationships attachment style. The results demonstrated a stable pattern of distinctions between centrality, social, communal, and interdependent identification. Most important, however, each of the investigated four types of ingroup identification appeared to vary independently as a function of attachment style, showing that particular prototypic attachment styles are associated with an increase in only certain types of identification. These findings supported the idea that relationship attachment style has an important effect on people's identification with social groups and can serve as a predictor of preferred types of ingroup identification. 


\section{References}

Ainsworth, M. S., Blehar, M. C., Waters, E., \& Wall, S. (1978). Patterns of attachment: A psychological study of the strange situation. Oxford, England: Lawrence Erlbaum.

Bartholomew, K., \& Horowitz, L. M. (1991). Attachment styles among young adults: A test of a four-category model. Journal of Personality and Social Psychology, 61, 226-244.

Bowlby, J. (1969). Attachment and loss: Vol. 1. Attachment. New York: Basic Books.

Bowlby, J. (1973). Attachment and loss: Vol. 2. Separation: Anxiety and anger. New York: Basic Books.

Bowlby, J. (1980). Attachment and loss: Vol. 3. Loss. New York: Basic Books.

Brennan, K. A., Shaver, P. R., \& Tobey, A. E. (1991). Attachment styles, gender and parental problem drinking. Journal of Social and Personal Relationships, 8, 451-466.

Clark, L. A., \& Watson, D. (1995). Constructing validity: Basic issues in objective scale development. Psychological Assessment, 7, 309-319.

Crisp, R. J., Farrow, C. V., Rosenthal, H. E., Walsh, J., Blissett, J., \& Penn, N. M. (2009). Interpersonal attachment predicts identification with groups. Journal of Experimental Social Psychology, 45, 115-122.

Gabriel, S., Carvallo, M., Dean, K., Tippin, B., \& Renaud, J. (2005). How I See Me Depends on How I See We: The Role of Attachment Style in Social Comparison. Personality and Social Psychology Bulletin, 31, 1561-1572.

Fraley, C., \& Shaver, P. (2000). Adult romantic attachment: Theoretical developments, emerging controversies, and unanswered questions. Review of General Psychology, 4, 132-154.

Hazan, C., \& Shaver, P. (1987). Romantic love conceptualized as an attachment process. Journal of Personality \& Social Psychology, 52, 511-524.

Mikulincer, M., Orbach, I., \& Iavnieli, D. (1998). Adult attachment style and affect regulation: Strategic variations in subjective self-other similarity. Journal of Personality and Social Psychology, 75, 436-448.

Milanov, M., Rubin, M., \& Paolini, S. (2012). Types of ingroup identification as a function of group type. Annual of Sofia University "St. Kliment Ohridski”: Book Psychology, 103.

Milanov, M., Rubin, M., \& Paolini, S. (in press). Constructing and validating a new measure of ingroup identification. Annual of Sofia University "St. Kliment Ohridski": Book Psychology, 104.

Prentice, D., Miller, D., \& Lightdale, J. (1994). Asymmetries in attachments to groups and to their members: Distinguishing between common-identity and common-bond groups. Personality \& Social Psychology Bulletin, 20, 484-493.

Smith, E. R., Murphy, J., \& Coats, S. (1999). Attachment to groups: Theory and management. Journal of Personality and Social Psychology, 77, 94-110.

Dr Milen Toshev Milanov, Chief Assistant Professor, Department of General, Experimental, and Genetic Psychology, Sofia University “St. Kliment Ohridski”, Tel. 02 9308476, mil.milanov@abv.bg

Dr Mark Rubin, Senior Lecturer, School of Psychology, University of Newcastle, Australia, Tel. ++61 24921

6706, mark.rubin@ newcastle.edu.au

Dr Stefania Paolini, Senior Lecturer, School of Psychology, University of Newcastle, Australia, Tel. ++61 2

49215938, stefania.paolini@newcastle.edu.au

Гл. ас. д-р Милен Тошев Миланов, СУ „Св. Климент Охридски”, Катедра “Обща, експериментална и генетична психологя“, Тел. 02 9308476, mil.milanov@abv.bg

Д-р Марк Рубин - Университет на Нюкасъл, Австралия, Департамент по Психология, Тел. ++61 24921

6706, mark.rubin@ @ewcastle.edu.au

Д-р Стефаниа Паолини - Университет на Нюкасъл, Австралия, Департамент по Психология, Тел. ++61 2

49215938, stefania.paolini@newcastle.edu.au 